\title{
PENGARUH VARIASI FILLER TERHADAP NILAI KEPADATAN UNTUK AGREGAT PASIR KASAR
}

\author{
Hamzani \\ Jurusan Teknik Sipil, Universitas Malikussaleh
}

\begin{abstract}
Abstrak
Campuran agregat sebagai bahan konstruksi perkerasan jalan raya sangat dipengaruhi mutu perkerasan, salah satu faktor adalah sifat agregat, gradasi, kepadatan dan daya dukung yang dinyatakan dengan CBR. Nilai CBR bergantung pada komposisi butiran agregat, kepadatan dan kekerasan. Penelitian ini untuk menyelidiki pengaruh variasi filler terhadap nilai kepadatan dan daya dukung perkerasan dari agregat pasir kasar. Dengan cara memvariasikan filler dari agregat pasir kasar bergradasi rapat dengan tingkat kepadatan berapa didapatkan daya dukung maksimum. Tahapan-tahapan penelitian yaitu pertama dengan melakukan percobaan pemadatan dengan Modified Proctor dan dilanjutkan percobaan CBR berdasarkan kadar air optimum yang didapat dari percobaan pemadatan. Komposisi filler yaitu $5 \%, 7 \%, 9 \%, 11 \%$ dan $13 \%$ terhadap berat total campuran. Rancangan benda uji kepadatan masing-masing variasi filler adalah variasi kadar air yaitu $6 \%$, $7 \%, 8 \%$, 9\% dan 10\%, sehingga jumlah benda uji $5 \times 5=25$ buah. Dari hasil pengujian kepadatan diperoleh pada kadar filler 5,\% didapat kadar air optimum 7,30\% dengan berat isi kering $\left(\gamma_{\mathrm{d}}\right)$ maksimum 2,788 $\mathrm{gr} / \mathrm{cm}^{3}$. Selanjutnya pengujian CBR pada setiap variasi filler dan tertinggi pada filler 9\% dengan kadar air optimum 7,85\% didapat nilai CBR laboratorium 86,66\%. Dari hasil di atas terlihat nilai CBR maksimum tidak terjadi pada campuran dengan tingkat kepadatan optimum.
\end{abstract}

Kata-kata kunci: kepadatan, daya dukung dan filler

\section{Pendahuluan}

Campuran agregat sebagai bahan konstruksi perkerasan jalan sangat mempengaruhi mutu perkerasan. Konstruksi perkerasan jalan yang baik adalah konstruksi perkerasan yang kuat dan mempunyai daya dukung yang tinggi. Salah satu faktor yang dapat mempengaruhi kemampuan perkerasan dalam menahan beban lalu lintas tersebut adalah sifat agregat, gradasi, kepadatan dan daya dukung yang dinyatakan dengan nilai CBR (California Bearing Ratio). Nilai CBR bergantung pada komposisi butiran agregat, kepadatan dan kekerasan. Komposisi butiran agregat terdiri dari beberapa kelompok ukuran yang lazim yaitu kelompok butiran kasar, butiran halus dan filler dalam batas ukuran yang telah ditentukan. Butiran-butiran agregat tersebut harus terdistribusi sesuai dengan komposisi masing-masing sehingga butiran halus akan mengisi rongga-rongga yang kosong di antara butir yang lebih kasar. Menurut Yoder dan Witczak (1975), bahwa nilai CBR maksimum terdapat pada tingkat kepadatan tertentu, maka berdasarkan kondisi tersebut dilakukan variasi komposisi filler terhadap material pasir kasar bergradasi rapat menurut spesifikasi yang dikutip dari Bukhari (2004) dengan menggunakan spesifikasi batas tengah sebagai acuran dalam melakukan penambahan dan pengurangan komposisi filler.

Pada penelitian ini dilakukan untuk melihat pengaruh komposisi filler pada tingkat kepadatan dan daya dukung material pasir kasar bergradasi rapat, dan daya dukung maksimum. 
Material yang digunakan adalah agregat pasir kasar yang berasal dari sungai Krueng Aceh lokasi Indrapuri Aceh Besar dengan kadar filler 9\%, kemudian dilakukan variasi penambahan dan pengurangan persen filler sehingga campuran menjadi sesuai spesifikasi. Sebelum dilakukan pengujian pemadatan dan CBR material terlebih dahulu diperiksa sifat-sifat fisis dan kadar air awal. Pemberian kadar air untuk memudahkan proses pemadatan yang didasarkan pada kadar air awal. Penelitian ini dilakukan dua tahap, tahap pertama yaitu melakukan percobaan pemadatan untuk memperoleh kadar air optimum dan kepadatan maksimum. Kadar air optimum tersebut dipergunakan untuk penelitian tahap kedua yaitu pengujian CBR dan diperoleh nilai CBR laboratorium pada setiap variasi variasi filler.

\section{Tujuan Penelitian}

Berdasarkan berbagai variasi filler tersebut di atas maka dapat dinyatakan bahwa tujuan dari penelitian ini adalah:

a. Menyelidiki pengaruh variasi filler terhadap campuran agregat pasir kasar sebagai material lapis perkerasan.

b. Mengetahui apakah nilai stabilitas tertinggi terjadi pada kadar filler yang menghasilkan nilai kepadatan maksimum.

\section{Pengujian Laboratorium}

\subsection{Pengujian sifat-sifat fisis agregat}

Agregat yang digunakan dalam penelitian diperoleh dari quarry Krueng Aceh dan filler (sebagai bahan pengisi) adalah dari abu batu agregat itu sendiri. Persyaratan sifat-sifat fisis agregat dalam penelitian ini adalah yang ditetapkan oleh AASHTO (1990). Dalam penlitian ini pemeriksaan sifat-sifat fisis agregat tidak dilakukan lagi, karena penelitian ini menggunakan material yang sama dengan Wahyudi (2005). Wahyudi telah melakukan pengujian sifat-sifat fisis agregat pecah Sungai Krueng Aceh dan data keseluruhan dari hasil pemeriksaan diperlihatkan pada Tabel 1.

Tabel 1 Data Hasil Pemeriksaan Sifat-sifat Fisis Agregat

\begin{tabular}{|l|l|l|l|}
\hline No. & \multicolumn{1}{|c|}{ Sifat-Sifat Fisis Agregat } & \multicolumn{1}{|c|}{ Syarat } & \multicolumn{1}{c|}{$\begin{array}{c}\text { Hasil } \\
\text { Pemeriksaan }\end{array}$} \\
\hline 1. & Berat isi & $>1 \mathrm{~kg} / \mathrm{dm}^{3}$ & $1,469 \mathrm{~kg} / \mathrm{dm}^{3}$ \\
2. & Berat jenis & $>2,50$ & 2,688 \\
3. & Brt jenis krng permukaan jenuh & $>2,50$ & 2,709 \\
4. & Berat jenis semu & $>2,50$ & 2,745 \\
5. & Penyerapan & $<3 \%$ berat & $0,770 \%$ berat \\
6. & Keawetan & $<12 \%$ berat & $3,50 \%$ berat \\
7. & Keausan & $<40 \%$ berat & $21,62 \%$ berat \\
8. & Indeks kepipihan & $<25 \%$ berat & $22,072 \%$ berat \\
9. & Indeks kelonjongan & $<25 \%$ berat & $16,063 \%$ berat \\
10. & Tumbukan (impact) & $<35 \%$ berat & $25,18 \%$ berat \\
\hline
\end{tabular}

Sumber: Wahyudi (2005) 


\subsection{Gradasi agregat}

Pemilihan gradasi agregat dalam penelitian ini menggunakan gradasi baik/rapat (dense graded) yang merupakan distribusi partikel-partikel dari agregat kasar sampai halus relatif berimbang. Jumlah filler yang dibutuhkan dalam gradasi ini secukupnya untuk menutupi rongga yang ada di antara butir-butir agregat kasar. Persyaratan bahan lapis perkerasan bergadasi baik untuk agregat pasir kasar diambil berdasarkan persen lolos saringan No.4>50\% dan spesifikasinya seperti diperlihat Tabel 2.

Tabel 2 Spesifikasi agregat pasir kasar gradasi rapat untuk lapis perkerasan

\begin{tabular}{|c|c|c|}
\hline \multicolumn{2}{|c|}{ Ukuran Saringan } & $\begin{array}{c}\text { Persen Lolos } \\
(\mathbf{\%})\end{array}$ \\
\cline { 1 - 2 } No. Saringan & Ukuran (mm) & 100 \\
\hline $3 / 8$ & 9,52 & 71 \\
\hline No.4 & 4,75 & 50 \\
\hline No.8 & 2,36 & 46 \\
\hline No.10 & 2,00 & 25 \\
\hline No.30 & 0,59 & 21 \\
\hline No.40 & 0,42 & 13 \\
\hline No.100 & 0,149 & 9 \\
\hline No.200 & 0,074 & \\
\hline Filler & $<0,074$ & \\
\hline
\end{tabular}

Sumber: Bukhari (2004)

\subsection{Pemeriksaan material filler}

Material filler sebelum digunakan/dicampur dengan agregat kasar terlebih dahulu diperiksa sifat-sifat fisisnya. Filler disyaratkan harus kering dan bebas dari gumpalan-gumpalan. Filler yang digunakan dalam penelitian ini adalah abu batu itu sendiri, sebagai material yang lolos pada saringan No.200 (0,074 mm).

\subsection{Pembuatan benda uji}

Agregat kasar dan agregat halus yang telah diperiksa dan memenuhi syarat/spesifikasi dan dibuat komposisi gradasi ukuran saringannya sesuai dengan yang direncanakan dengan gradasi rapat. Pada tahap awal ditentukan jumlah filler (P) yang akan dijadikan sebagai dasar penentuan variasi kadar filler dengan menggunakan rumus Talbot. Setelah diketahui jumlah filler (P) maka dibuat variasi kadar filler dengan menetapkan $1 \%$ dan $2 \%$ di bawah (P) serta $1 \%$ dan $2 \%$ di atas $(\mathrm{P})$. Kemudian material yang bergradasi baik tersebut selanjutnya dibuat satu benda uji seberat 5000 gram. Berat masing-masing ukuran saringan sesuai dengan distribusi gradasi rapat. Tiap variasi kadar filler dibuat 5 buah benda uji yaitu $6 \%, 7 \%, 9 \%, 11 \%$ dan 13\%, sehingga jumlah benda uji tersebut adalah $5 \times 5=25$ buah. Agregat yang telah dicampur sesuai dengan porsi, kemudian dimasukkan ke dalam talam dan agregat tersebut diberikan kadar air sesuai dengan jenis agregat. Menurut Ismail (1995) pemberian kadar air didasarkan pada patokan, kadar air yang diberikan adalah 5\%, 7\%, 9\%, 11\% dan $13 \%$.

Berat air dihitung didasarkan pada kadar awal, kekurangannya ditambah berdasarkan persen kadar yang diperlukan. Metode penambahan air yaitu, benda 
uji yang telah diberikan kadar air, lalu diaduk sedemikian rupa sehingga merata, lalu benda uji dimasukkan ke dalam kantong platik dan dibiarkan selama 24 jam lalu dipadatkan. Selanjutnya agregat tersebut dipersiapkan untuk pemadatan dan test CBR, Pada percobaan CBR, dibuat 3 benda uji untuk masing-masing komposisi filler. Sehingga total benda uji untuk percobaan CBR adalah $3 \times 5=15$ benda uji. Kadar air yang digunakan pada test CBR tersebut adalah kadar optimum yang didapat pada test kepadatan.

\subsection{Pengujian Pemadatan Proctor}

Benda uji yang telah disiapkan selanjutnya dilakukan pemadatan dengan menggunakan alat uji pemadatan Modified Proctor. Pemadatan ini dilakukan sesuai standar AASHTO (1990) yang diambil dari Anonim (1994). Benda uji dipadatkan dalam cetakan silinder bervolume 1766, $25 \mathrm{~cm}^{3}$, diameter cetakan adalah 6 inci $(15 \mathrm{~cm})$. Benda uji dipadatkan dalam 5 lapisan dengan menggunakan penumbuk seberat $10 \mathrm{lb}(4,54 \mathrm{~kg})$, tinggi jatuh penumbuk adalah 18 inci $(45 \mathrm{~cm})$, jumlah tumbukan perlapis adalah 56 kali untuk setiap lapisan.

Berdasarkan berat agregat dibagi volume agregat diperoleh berat vulume agregat $(\gamma)$, kemudian dari berat volume agregat tersebut didapat berat volume agregat kering $\left(\gamma_{\mathrm{k}}\right)$. Kemudian berdasarkan data tersebut di buat grafik hubungan antara kadar air dengan gama kering material/density $\left(\gamma_{\mathrm{k}}\right)$ untuk mendapatkan kadar air optimum yang menghasilkan kepadatan maksimum $\left(\gamma_{\mathrm{k} \text { maks }}\right)$, seperti diperlihatkan pada Gambar 1.

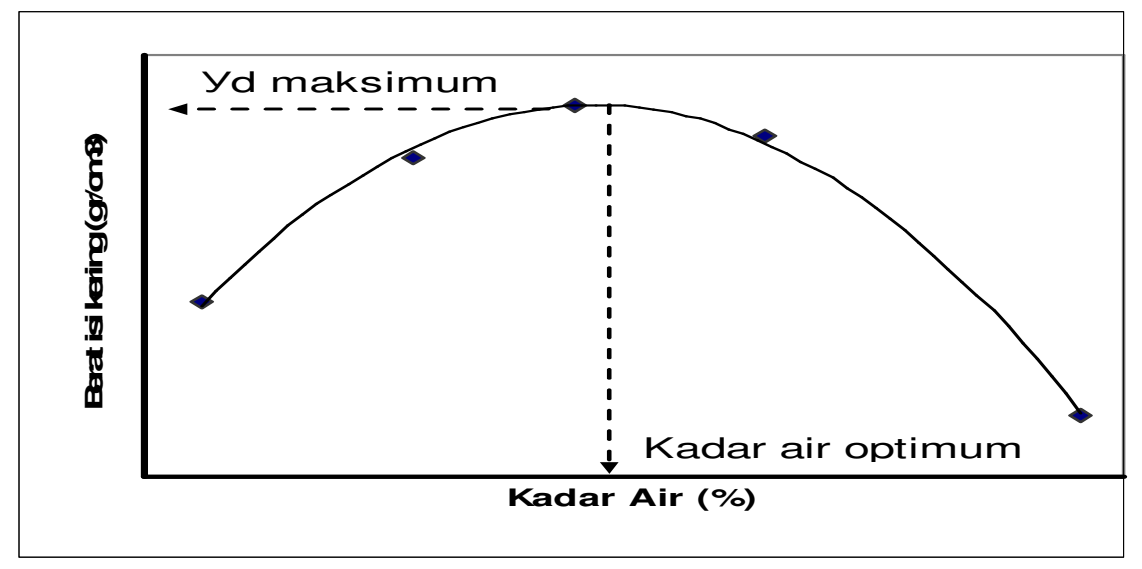

Gambar 1 Hubungan antara kadar air dengan berat isi kering Sumber: Wesley (1977)

\subsection{Pengujian California Bearing Ratio (CBR)}

Benda uji yang telah pemadatan dilakukan pengujian penetrasi dengan menggunakan mesin penetrasi (loading machine) berkapasitas 4,45 ton (10.000 lbs) dengan kecepatan penetrasi $1,27 \mathrm{~mm}(0,05$ inc) per menit, dalam arah vertikal. Pengukuran beban di catat pada penetrasi 0,1 in $(2,5 \mathrm{~mm})$ sampai dengan penetrasi 0,5 inch $(12,5 \mathrm{~mm})$. 
Nilai penetrasi yang diambil untuk menghitung nilai CBR adalah nilai pada penetrasi 0,1 dan 0,2 inch. Nilai-nilai tersebut diplot ke dalam grafik yang menyatakan hubungan antara kadar filler dengan nilai CBR, dimana pada kadar filler optimum akan diperoleh daya dukung maksimum yaitu berupa nilai CBR maksimum.

\section{Hasil dan Pembahasan}

\subsection{Hasil percobaan}

Dari hasil pengujian pada percobaan di atas disajikan hasil percobaan pemadatan dan hasil percobaan CBR sebagai berikut:

\subsubsection{Hasil percobaan pemadatan}

Pada percobaan pemadatan dengan Modified Proctor pasir kasar bergradasi baik dengan variasi komposisi filler yang digunakan dalam campuran 5\%, 7\%, $9 \%, 11 \%$ dan $13 \%$ terhadap berat total campuran. Sebelum dilakukan pemadatan, distribusi agregat sudah sesuai dengan gradasi yang dipilih yaitu gradasi baik, maka penggunaannya sudah sesuai dengan persentase lolos setiap ukuran saringan. Pada pengujian pemadatan dengan Modified Practor yang telah dilakukan sesuai metode pelaksanaan, diperoleh hasil pemadatan pada masingmasing variasi filler. Hasil pengujian kepadatan diperlihatkan pada Tabel 3.

Tabel 3. Nilai kadar air optimum dan berat isi kering $\left(\gamma_{\mathbf{d}}\right)$ maksimum

\begin{tabular}{|c|c|c|c|c|}
\hline \multirow{3}{*}{ No. } & \multirow{3}{*}{ Agregat } & $\begin{array}{c}\text { Kadar Filler } \\
(\boldsymbol{\%})\end{array}$ & $\begin{array}{c}\text { Kadar Air } \\
\text { Optimum } \\
(\boldsymbol{\%})\end{array}$ & $\begin{array}{c}\text { Berat Isi Kering } \\
\left(\gamma_{\mathrm{d}}\right) \mathbf{m a k s .}\left(\mathbf{g r} / \mathbf{c m}^{\mathbf{3}}\right)\end{array}$ \\
\hline \multirow{3}{*}{1.} & \multirow{3}{*}{ Pasir Kasar } & 5 & 7,80 & 2,577 \\
\cline { 3 - 5 } & & 7 & 8,85 & 2,649 \\
\cline { 3 - 5 } & & 11 & 7,85 & 2,764 \\
\cline { 3 - 5 } & & 13 & 7,30 & 2,788 \\
\cline { 3 - 5 } & & & 7,30 & 2,761 \\
\hline
\end{tabular}

Dari hasil tersebut dibuat grafik hubungan antara kadar air (Wi) dengan berat isi kering $\left(\gamma_{\mathrm{k}}\right)$ untuk mendapatkan kadar air optimum, dimana pada kadar air optimum diperoleh berat isi $\left(\gamma_{\mathrm{d}}\right)$ maksimum.

Tingkat kepadatan yang diperoleh dari uji kepadatan berdasarkan kadar air optimum pada agregat kerikil pecah yang menghasilkan berat isi $\left(\gamma_{\mathrm{d}}\right)$ maksimum tertinggi yaitu pada kadar filler 5\% didapat nilai kadar air optimum $8,10 \%$ dengan berat isi kering $\left(\gamma_{\mathrm{d}}\right)$ maksimum $2,826 \mathrm{gr} / \mathrm{cm}^{3}$, dan terendah pada kadar filler $1 \%$ didapat nilai kadar air optimum 6,50\% dengan berat isi kering $\left(\gamma_{\mathrm{d}}\right)$ maksimum $2,638 \mathrm{gr} / \mathrm{cm}^{3}$. Untuk lebih rinci nilai-nilai tersebut diperlihatkan pada Gambar 2. 


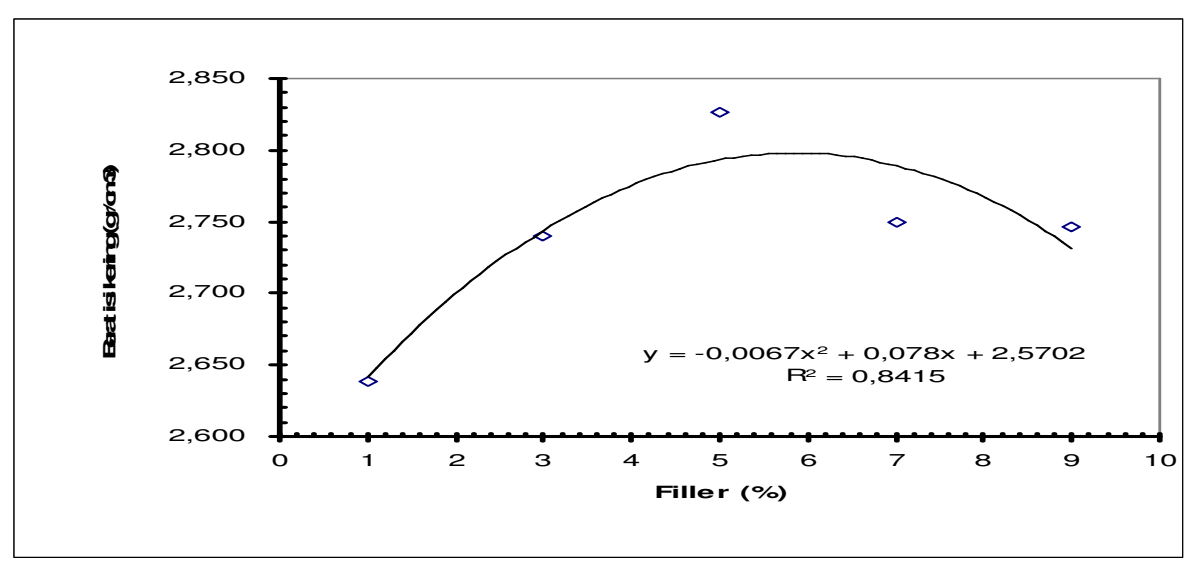

Gambar 2. Hubungan berat isi kering optimum pada setiap variasi persen filler dengan kadar filler untuk material kerikil pecah.

\subsubsection{Hasil percobaan CBR}

Berdasarkan hasil percobaan CBR yang dilaksanakan pemadatan berdasarkan kadar air optimum pada material agregat pasir kasar untuk masingmasing variasi komposisi filler 5\%,7\%, 9\%, 11\% dan 13\% terhadap berat total capuran agregat.

Dari hasil percobaan CBR agregat pasir kasar untuk setiap variasi filler diperoleh nilai CBR terendah adalah pada filler 5\% dengan kadar air optimum $7,80 \%$ didapat nilai CBR laboratorium $70,00 \%$, dan nilai CBR tertinggi pada filler 9,0\% dengan kadar air optimum 7,85\% didapat nilai CBR laboratorium 86,66\%. Hasil dari percobaan CBR tersebut diperlihatkan pada Tabel 4.

Tabel 4 Hasil percobaan CBR untuk agregat kerikil pecah dan pasir kasar pada masing-masing kadar persen filler.

\begin{tabular}{|c|c|c|c|c|}
\hline \multirow{3}{*}{ No. } & \multirow{3}{*}{ Jenis Agregat } & $\begin{array}{c}\text { Kadar } \\
\text { Filler } \\
(\boldsymbol{\%})\end{array}$ & $\begin{array}{c}\text { Kadar Air } \\
\text { Optimum }\end{array}$ & $\begin{array}{c}\text { Nilai CBR } \\
\mathbf{( \% )}\end{array}$ \\
\hline \multirow{3}{*}{1.} & \multirow{3}{*}{ Pasir Kasar } & 5 & 7,80 & \\
\cline { 3 - 5 } & & 7 & 8,85 & 70,00 \\
\cline { 3 - 5 } & & 9 & 7,85 & 86,68 \\
\cline { 3 - 5 } & & 11 & 7,30 & 71,11 \\
\cline { 3 - 5 } & & 13 & 7,30 & 81,11 \\
\hline
\end{tabular}

Berdasarkan data tersebut untuk mengetahui daya dukung maksimum terdapat pada campuran dengan komposisi filler berapa, maka dibuat grafik yang menyatakan hubungan antara nilai CBR maksimum dengan kadar filler pada setiap variasi filler. Berikut ini ditampilkan grafik hubungan nilai CBR maksimum dengan kadar filler seperti diperlihatkan pada Gambar 3. 


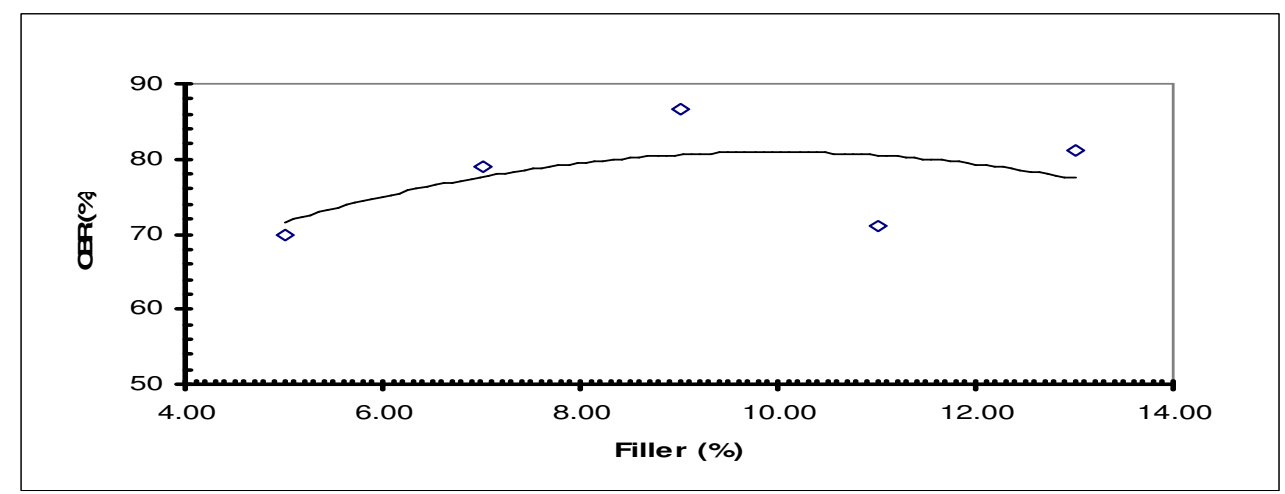

Gambar 3 Hubungan CBR maksimum dengan setiap variasi filler untuk agregat pasir kasar.

Dari grafik di atas diperoleh kadar filler optimum yang dapat menghasilkan nilai CBR tertinggi dari agregat pasir kasar, dan nilai CBR tertinggi tidak diperoleh pada kadar filler $(11 \%)$ yang menghasilkan nilai kepadatan tertinngi $\left(2,764 \mathrm{gr} / \mathrm{cm}^{3}\right)$ tetapi berkurang sedikit yaitu pada filler $11 \%$ dengan nilai CBR laboratorium maksimum 86,66\%.

Dari kedua grafik diatas, diperoleh suatu hubungan antara kadar filler, nilai kepadatan, dan CBR. Grafik ini menunjukkan bahwa nilai CBR maksimum tidak terjadi pada tingkat kepadatan optimum, hubungan tersebut diperlihatkan pada Gambar 4.

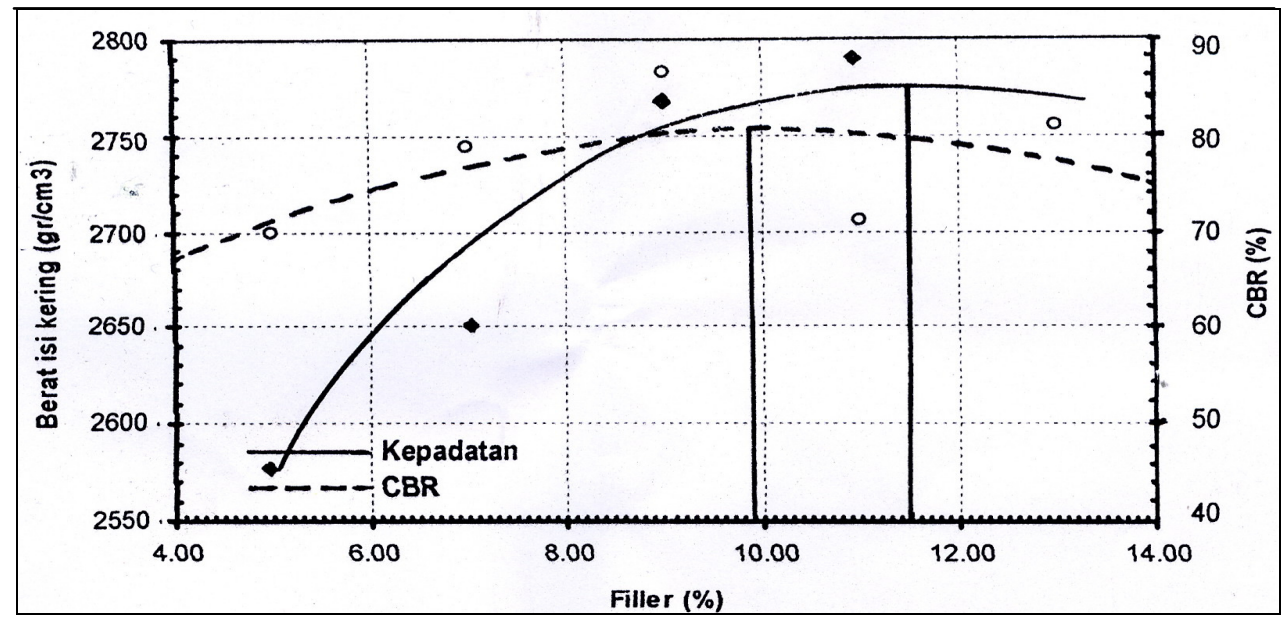

Gambar 4. Grafik Hubungan Kepadatan dan CBR terhadap persen Filler

\subsection{Pembahasan}

Dari percobaan pemadatan yang dilakukan berdasarkan kadar air pada variasi komposisi filler 5\%, 7\%, 9\%, 11\% dan 13\% dari agregat pasir kasarh, diperoleh nilai kadar air optimum dan nilai kepadatan. Kadar air optimum yang didapat pada variasi komposisi filler yaitu semakin tinggi kadar filler semakin rendah kadar optimum yang didapat. Hal ini disebabkan jumlah agregat yang lolos No. 4>50\% umumnya pasir tidak menyerap air dan kadar rongga di dalam campuran pasir relatif kecil sehingga variasi filler ditambah kadar air menurun. 
Adapun nilai kepadatan diperoleh nilai kepadatan tertinggi pada campuran dengan kadar filler 11,5 dengan berat isi kering $\left(\gamma_{\mathrm{k}}\right)$ maksimum 2,780 gr/ $/ \mathrm{cm}^{3}$.

Dari hasil tersebut bahwa terjadi perbedaan sedikit antara Yoder dan Witczak dengan hasil yang didapat, hal disebabkan jenis dan sifat properties agregat pada Yoder dan Witczak tidak diperlihatkan. Dimana daya dukung maksimum untuk jenis agregat tersebut tidak terjadi pada campuran dengan tingkat kepadatan tertinggi, namun berkurang sedikit. Hal ini kemungkinan disebabkan pada saat dilakukan uji CBR setelah pemadatan, terjadi kehancuran agregat akibat proses pemadatan sehingga komposisi filler bisa bertambah pada campuran tersebut.

\section{Kesimpulan}

Berdasarkan hasil pengujian pada percobaan dan pembahasan yang dilakukan dapat disimpulkan sebagai berikut:

1. Pada uji kepadatan pada setiap variasi komposisi filler yang dilakukan berdasarkan kadar air diperoleh berat isi kering $\left(\gamma_{\mathrm{d}}\right)$ maksimum dan kadar air optimum, dengan menggunakan grafik hubungan antara kadar filler dengan nilai kepadatan yang didapat pada kadar air optimum maka diperoleh pada kadar filler $11,5 \%$ dengan berat isi kering $\left(\gamma_{\mathrm{k}}\right)$ maksimum $2,780 \mathrm{gr} / \mathrm{cm}^{3}$.

2. Pada uji CBR yang dilakukan berdasarkan kadar air optimum pada material agregat pasir kasar untuk masing-masing variasi komposisi filler diperoleh nilai CBR maksimum pada kadar filler 9,95\% dengan nilai CBR 81\%. Dengan demikian nilai CBR maksimum tidak diperoleh pada kadar filler yang menghasilkan nilai kepadatan maksimum, dimana terjadi selisih nilai kadar filler sebesar $1,60 \%$.

Pada penelitian selanjutnya direkomendasikan untuk meneliti bukan hanya dengan jumlah filler saja, tetapi dengan jenis filler dan material yang berbeda baik dari jenis maupun tempat pengambilannya. Dan pada penelitian ini faktor kekerasan tidak dijadikan variabel, sedangkan faktor tersebut ikut mempengaruhi persen filler akibat kehancuran pada saat pemadatan, dimana persen filler mempengaruhi pada besarnya nilai kepadatan dan daya dukung.

\section{Daftar Kepustakaan}

1. AASHTO, 1990, Standard Specification for Transportation Materials and Method of Sampling ang Testing, ed, 15 ${ }^{\text {th }}$, Washington D.C.

2. Anonim, 1987, Petunjuk Pelaksanaan Lapis Aspal Beton (Laston) untuk Jalan Raya, SNI No. 1737-1989-F, Departemen Pekerjaan Umum, Jakarta.

3. Anonim, 1994, Petunjuk Pelaksanaan Pekerjaan Laboratorium Jalan, Universitas Syiah Kuala, Banda Aceh. 
4. Bowles, J.E., 1991, Sifat-Sifat Fisis dan Geoteknik Tanah, Terjemahan Hainim J.K., Erlangga, Jakarta.

5. Bukhari, et al., 2004, Rekayasa Bahan dan Tebal Perkerasan Jalan Raya, Jurusan Teknik Sipil, Universitas Syiah Kuala, Banda Aceh.

6. Das, B.M., 1993, Mekanika Tanah (Prinsip-Prinsip Rekayasa Geoteknik), J.K., Erlangga, Jakarta.

7. Hines, W.W., dan D.C.Montgomery, 1990, Probabilita dan Statistik Dalam Ilmu Rekayasa dan Manajemen, Terjemahan Rudiansyah, Penerbit Universitas Indonesia, Jakarta.

8. Ismail, M.A., 1995, Petunjuk Praktikum Mekanika Tanah, Fakultas Teknik Universitas Syiah Kuala, Banda Aceh.

9. Krebs, R.D, and R.D. Walker, 1971, Highway Materials, Mc. Graw Hill Book Company, New York.

10. Sukirman, S., 1999, Perkerasan Lentur Jalan Raya, Penerbit Nova, Bandung.

11. Wahyudi, 2005, Perubahan Gradasi Akibat Pemadatan Ditinjau Terhadap Kekerasan Agregat Bergradasi Seragam, Fakultas Teknik Universitas Syiah Kuala, Darussalam Banda Aceh.

12. Wesley, L.D., 1977, Mekanika Tanah, Cetakan Ke Enam, Badan Penerbit Pekerjaan Umum, Jakarta.

13. Woods, et al.,1960, Highway Engineering Handbook, McGraw-Hill Book Company, New York.

14. Yoder, E.J., and M.W. Witczak, 1975, Principles of Pavement Design, John Wiley \& Sons, Inc, New York. 